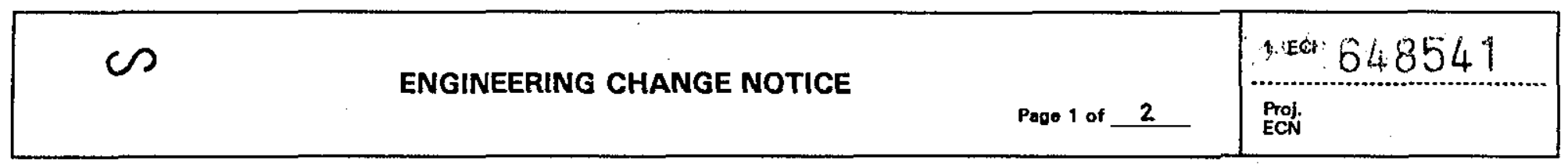

\begin{tabular}{|ll}
\hline 2. ECN Category (mark one) \\
Supplemental & $\bigcirc$ \\
Direct Revision & \\
Change ECN & $\bigcirc$ \\
Temporary & $\bigcirc$ \\
Standby & $\bigcirc$ \\
Supersedure & $\bigcirc$ \\
CancelNoid & $\bigcirc$ \\
\hline
\end{tabular}

12a. Modification Work

$\bigcirc$ Yes (fill out Blk. 12b)

O No (NA Blks. $12 b$,

3. Originator's Name, Organization, MSIN, and Telephone No.

B. R. Johns, ISE, S7-24, 373-3429

4. USQ Required? 5. Date

O

6. Project Title/No.Nork Order No.

Interim Stabilization, Leak

Detector Dedication, 103361

9. Document Numbers Changed by this ECN (includes sheet no. and rev.)

HNE-4275, revision 2

$12 / 10 / 99$

12b. Work Package No. 1 12c. Modification Work Completed

\begin{tabular}{l} 
7. Bidg./Sys./Fac. \\
241-G/200 \\
10. Related ECN \\
/A \\
\hline leted
\end{tabular}

OYes Ono

8. Approval Designator

N/A

$\mathrm{N} / \mathrm{A}$ Design Authority/Cog. Engineer Signature \&

13b. Design Baseline Document? $O$ Yes $O$ No

13a. Description of Change

This ECN is a direct revision of document HNF-4275, Commercial Grade Item Dedication for Leak
Detection Relays. The revision changes steps 6.1 .5 through 6.1 .27 and adds steps 6.1 .28

through 6.1.42. Step 6.2.1, is changed and steps 6.2.19, 6.2.23, 6.2.27, 6.2.31, 6.2.35, 6.2 .39 , and 6.2 .43 were added to section 6.2 . The references in section 12 were updated. The data sheets and sketches were changed to reflect the changes in the steps in sections 6.1 and 6.2 .

14a. Justification (mark one)
Criteria Change
Design Improvement
Environmental
Facility Deactivation
As-Found
Facilitate Const.
Const. Error/Omission
Design Error/Omission

14b. Justification Details

O This direct revision of HNF-4275 reflects the changes in the site wide

$O$ procedure 7-LDD-483 for leak detector relay dedication bench testing.

Design verification by Inform review per HNE-IP-0842, volume IV, section

4.24. USQ tracking \#TF-99-0973, revision 0 .

This direct revision will not change collective dose since it has no

impact on radiological sources, contamination control or shielding.

A NEPA review is not required since this is an administrative change per HNF-PRO-452, section 2.1, paragraph 10 .

15. Distribution (include name, MSIN, and no. of copies)

$\begin{array}{lll}\text { F. A. ZAK } & S 7-34 \\ \text { B. R. Johns } & S 7-24 \\ \text { M. R. Koch } & S 7-24 \\ \text { G. J. Coleman } & S 7-24 \\ \text { T. J. Volkman } & S 7-34 \\ \text { W. F. Zuroff } & S 7-24\end{array}$

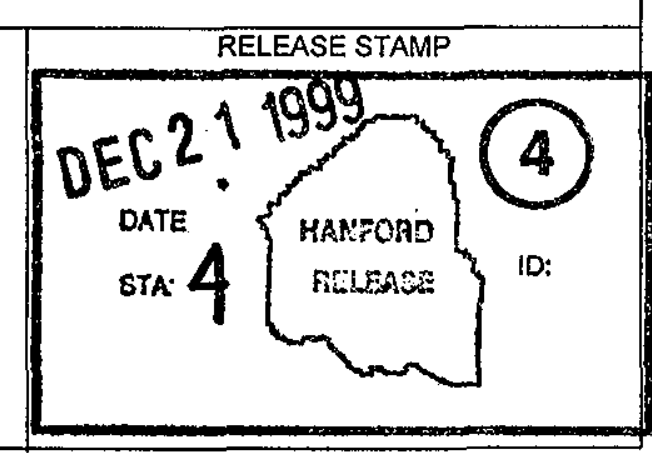


ENGINEERING CHANGE NOTICE

16. Design Verification Required
Y Yes
No

17. Cost Impact

ENGINEERING

Additional $\bigcirc \$ \underline{N} / \mathrm{A}$

Savings $\bigcirc \$ \mathrm{~N} / \mathrm{A}$
Page 2 of 2

\section{CONSTRUCTION}

Additional $\bigcirc \$ N / A$

Savings $\bigcirc \$ N / A$
1. ECN (use no. from pg. 1) 648541

18. Schedule Impact (days)

Improvement

$\mathrm{N} / \mathrm{A}$

Delay

$\mathrm{N} / \mathrm{A}$

19. Change Impact Review: Indicate the related documents (other than the engineering documents identified on Side 1) that will be affected by the change described in Block 13. Enter the affected document number in Block 20.

SDD/DD

Functional Design Criteria

Operating Specification

Criticality Specification

Conceptual Design Report

Equipment Spec.

Const. Spec.

Procurement Spec.

Vendor Information

OM Manual

FSAR/SAR

Safety Equipment List

Radiation Work Permit

Environmental Impact Statement

Environmental Report

Environmental Permit

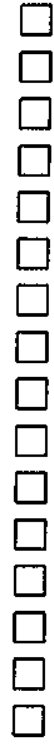

Seismic/Stress Analysis
Stress/Design Report
Interface Control Drawing
Calibration Procedure
Installation Procedure
Maintenance Procedure
Engineering Procedure
Operating Instruction
Operating Procedure
Operational Safety Requirement
IEFD Drawing
Cell Arrangement Drawing
Essential Material Specification
Fac. Proc. Samp. Schedule
Inspection Plan
Inventory Adjustment Request

Tank Calibration Manual Health Physics Procedure Spares Multiple Unit Listing Test Procedures/Specification Component Index ASME Coded Item Human Factor Consideration Computer Software

Electric Circuit Schedule ICRS Procedure Process Control Manual/Plan Process Flow Chart Purchase Requisition Tickler File

NONE

20. Other Affected Documents: (NOTE: Documents listed below will not be revised by this ECN.) Signatures below indicate that the signing organization has been notified of other affected documents listed below. Document Number/Revision

$N / A$
Document Number/Revision

Document Number/Revision

21. Approvals

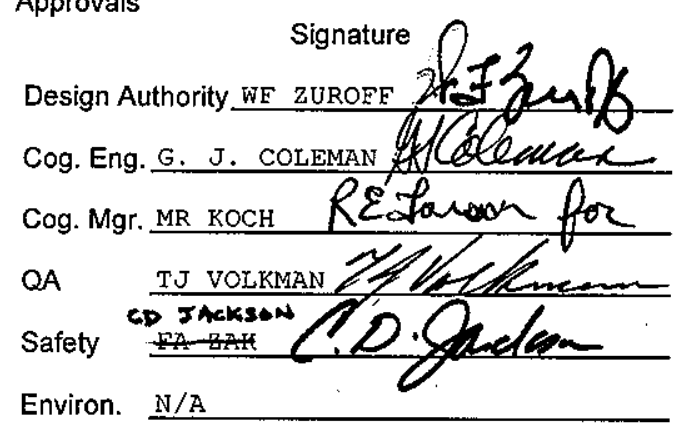

Other Informal Review: D. Aefd
$N / A$
$\mathrm{N} / \mathrm{A}$
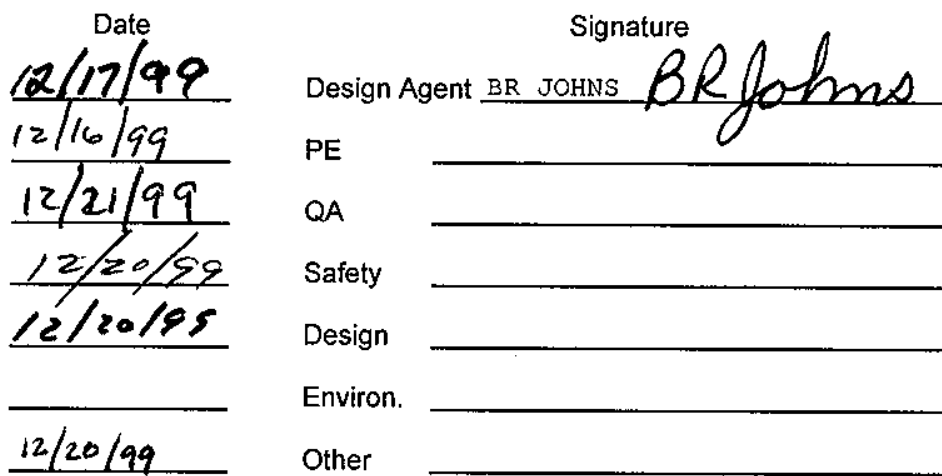

DEPARTMENT OF ENERGY

Signature or a Control Number that tracks the Approval Signature

ADDITIONAL

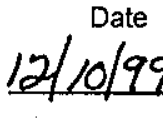
Date 


\title{
COMMERCIAL GRADE ITEM DEDICATION FOR LEAK DETECTION RELAYS
}

M. R. Koch

LOCKHEED MARTIN HANFORD CORPORATION

Richland, WA 99352

U.S. Department of Energy Contract DE-AC06-96RL13200

\author{
EDT/ECN: 648541 UC: \\ Org Code: 74D00 Charge Code: 103361 \\ B\&R Code: Ew3120071 Total Pages: 17
}

Key Words: PICS, SALT WELL, SKID, INTERIM STABILIZATION, LEAK DETECTION

Abstract: This Test Plan provides a test method to dedicate the leak detection relays used on the new Pumping and Instrumentation Control (PIC) skids. The new skids are fabricated on-site. The leak detection system is a safety class system per the Authorization Basis.

TRADEMARK DISCLAIMER. Reference herein to any specific commercial product, process, or service by trade name, trademark, manufacturer, or otherwise, does not necessarily constitute or imply its endorsement, recommendation, or favoring by the United States Government or any agency thereof or its contractors or subcontractors.

Printed in the United States of America. To obtain copies of this document, contact: Document Control Services, P.O. Box 950, Mailstop H6-08, Richland WA 99352, Phone (509) 372-2420; Fax (509) 376-4989.

$\underset{\text { Release Approval }}{\text { Xnis braden }} 12 / 21 / 99$

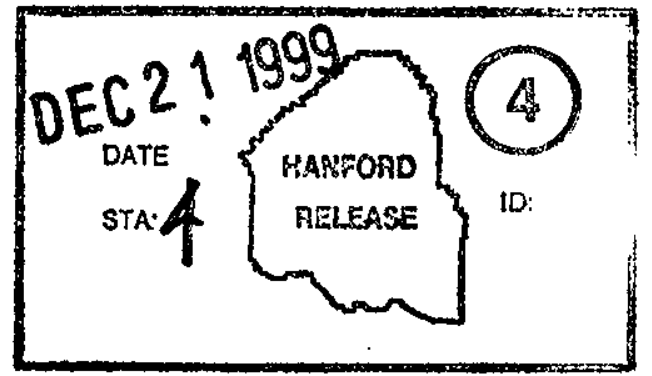

Release Stamp

\section{Approved For Public Release}




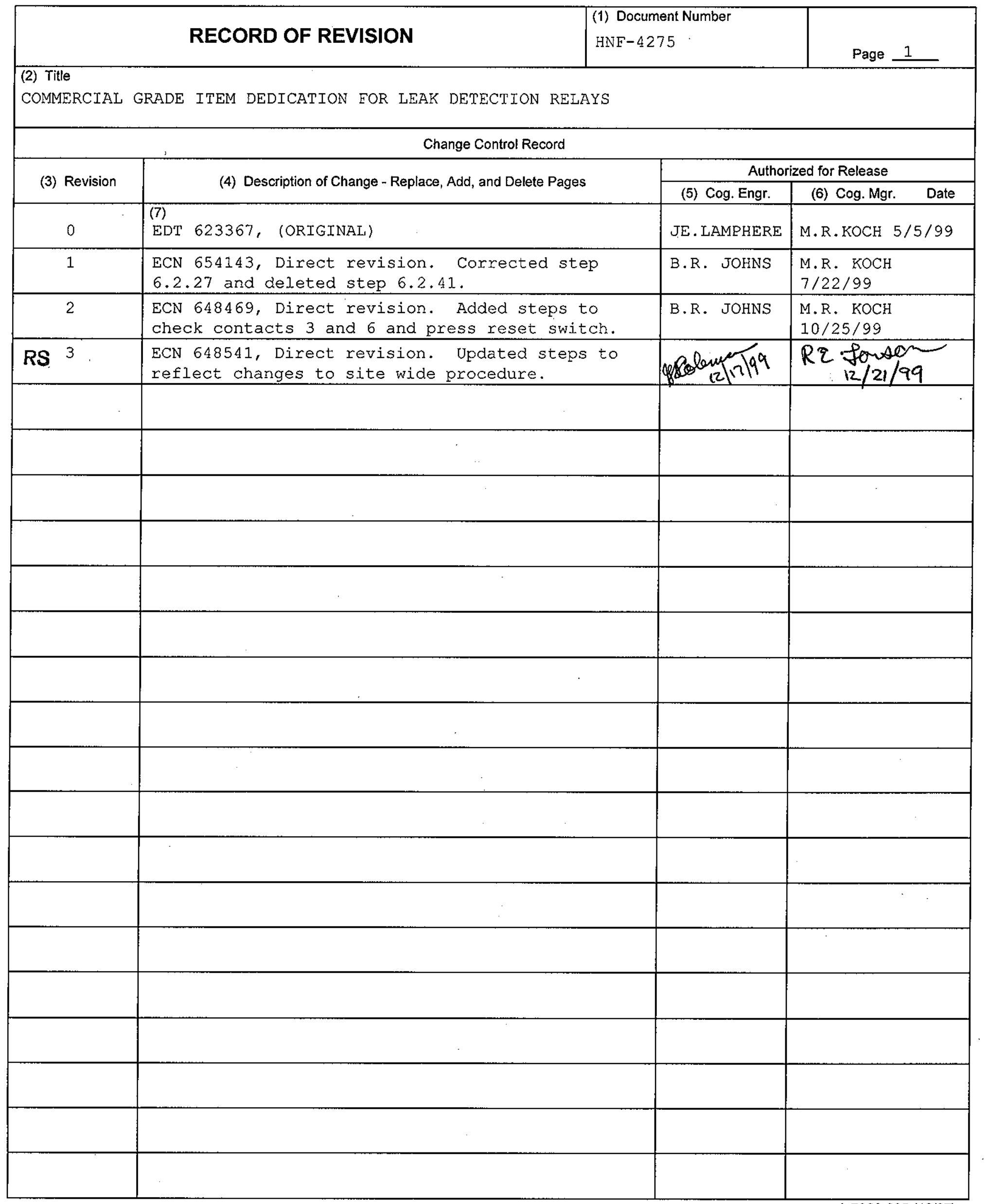


HNF-4275

REVISION 3

TABLE OF CONTENTS

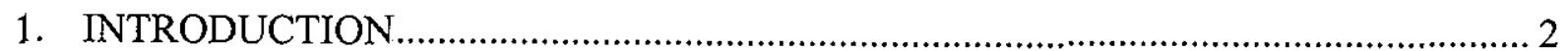

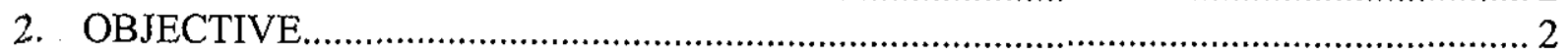

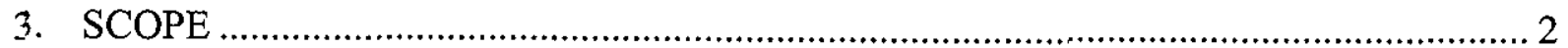

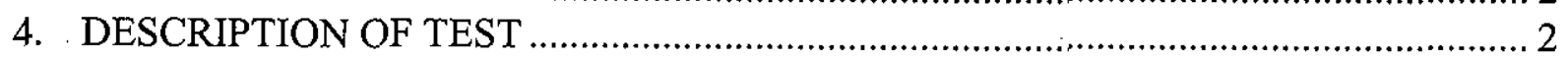

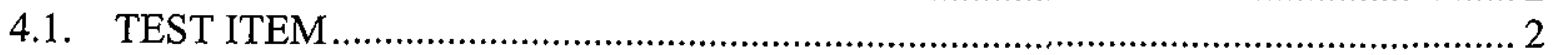

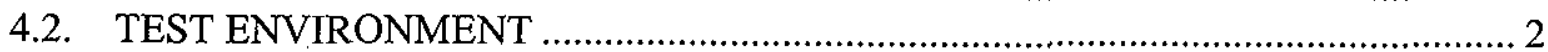

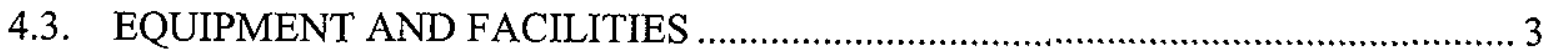

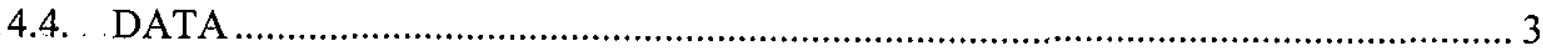

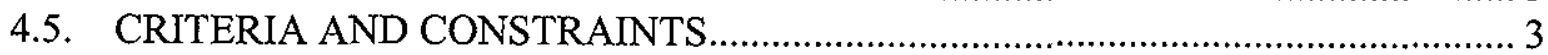

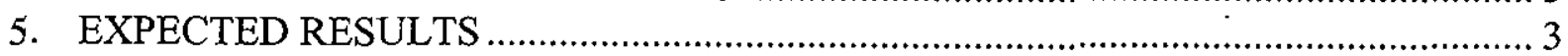

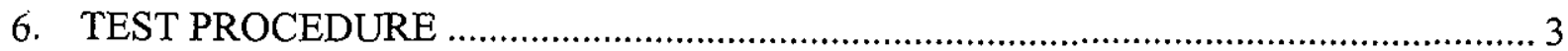

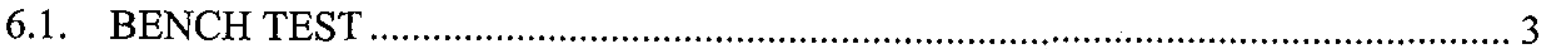

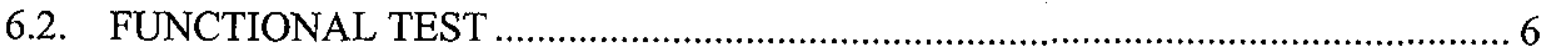

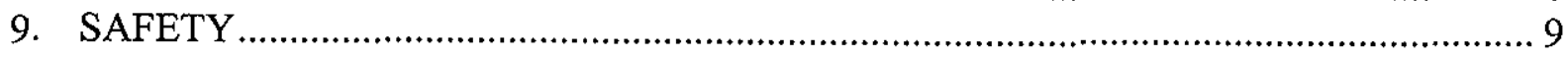

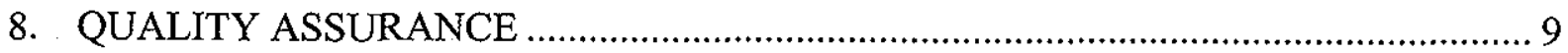

9. ORGANIZATION AND FUNCTION RESPONSIBILITIES …............................... 9

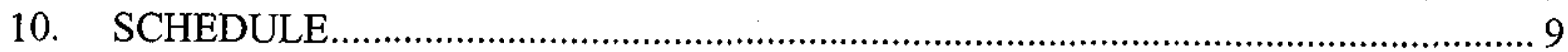

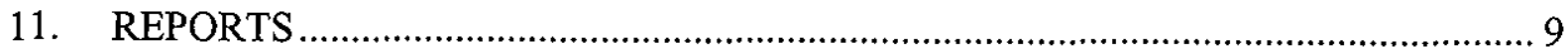

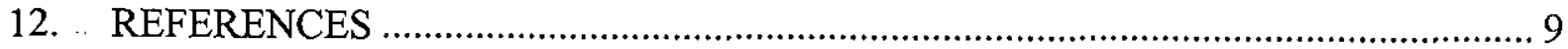

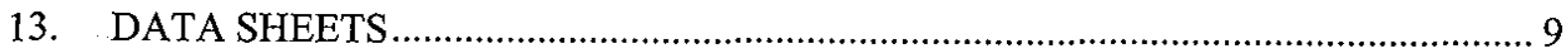

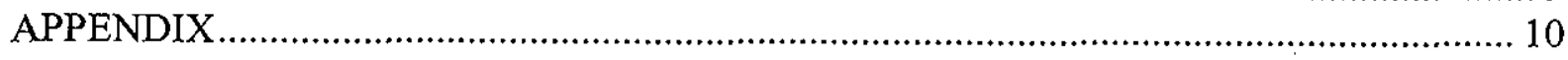


HNF-4275

REVISION 3

\section{COMMERCIAL GRADE ITEM UPGRADE DEDICATION FOR LEAK DETECTION} RELAYS

\section{INTRODUCTION}

This commercial grade item upgrade dedication test is for the leak detection relays installed on the Pumping Instrumentation and Control (PIC) skids. The PIC skids are used by Interim Stabilization for pumping liquids out of the underground waste tanks. There are two sets of leak detection relay assemblies on each PIC skid. The primary leak detection relay assembly is to monitor the pump pit of the tank being pumped. The second leak detection relay assembly monitors other areas along the transfer line during pumping such as Clean Out Boxes (COB). The leak detection relay assembly is considered Safety Class per the Authorization Basis (MI1C 1999a), chapter 3, tables 3.4.2.74 and 3.4.2.8.4.

\section{OBJECTIVE}

The testing outlined in this test procedure will dedicate the two relays used in each leak detector assembly on the PIC skids. These relays are intrinsically safe type relays.

\section{SCOPE}

This test covers the 5300-S-V-OC (or 5300-S-F1-OC) and the 2313A relays used in leak detection assemblies. Upon successful completion and passing of the testing outlined in this procedure, the relays are considered dedicated and can be green tagged and installed in the leak detection units.

\section{DESCRIPTION OF TEST}

\subsection{TEST ITEM}

The items to be tested are the relays in the leak detection assembly. These leak detection assemblies contain B/W Controls relay part number $5300-\mathrm{S}-\mathrm{V}-\mathrm{OC}$, a variable sensitivity (or 5300-S-F1-OC, a fixed sensitivity relay) and MTL relay part number 2313A.

\subsection{TEST ENVIRONMENT}

The bench test will be performed in the shop and the functional test will be performed during the Acceptance Test Procedure (ATP) or Operational Test Procedure (OTP) of the leak detection assembly. 
HNF-4275

REVISION 3

\subsection{EQUIPMENT AND FACILITIES}

Test equipment required is listed below. Calibration is required for the digital voltmeter.

- Digital voltmeter for voltage checks

- Test box to check the B/W Controls relay (Coordinate use with Interim Stabilization maintenance.)

- Bucket of water to test leak detector probe.

- Leak detector probe (Coordinate with Interim Stabilization for probe to use for testing).

- DC power supply for $3.5 \mathrm{vdc}$ to $4.0 \mathrm{vdc}$ for testing relay.

- A nominal $120 \mathrm{vac}$ power source to connect to the leak detection assembly.

\subsection{DATA}

The test procedure section and data tables identify the parameters to be checked and the acceptable values. The data is primarily voltages and relay contact opening and closing.

\subsection{CRITERIA AND CONSTRAINTS}

The criteria for acceptance of the relays is based upon proper functioning of the relays during the testing. The relays must function $100 \%$ correct to be acceptable. There are no other controlling documents the relays must comply with to be acceptable.

\section{EXPECTED RESULTS}

The relays must function $100 \%$ correct which includes all contacts operations and voltage measurements to meet the acceptance criteria as listed on the data sheets.

\section{TEST PROCEDURE}

\subsection{BENCH TEST}

6.1.1. Bench test the Intrinsically Safe 5300-S-V-OC (or 5300-S-F1-OC) (5300) relay as per the following steps:

6.1.2. Use a calibrated digital voltmeter. Record calibration data on data sheet. 
HNF-4275

REVISION 3

6.1.3. Identify the relays to be tested with a label. Label one as "SALW-LDE6001 " and the other as "SALW-LDE-6002*". Document the number in the component ID column of the data sheets, one on each data sheet. Replace the * with the skid identification letter.

6.1.4. Quality Assurance Inspector to verify the correct part number of 5300-S-VOC (or 5300-S-F1-OC) of the relay that is being tested. Record on the data sheet.

6.1.5. Verify resistance between terminal 12 on the 5300 relay and chassis ground with a YOM is greater than $10 \mathrm{M}$ ohm Record reading on the data sheet

6. 1.6. If the 5300 relay does not meet 1 he $10 \mathrm{M}$ ohms resistance in step $6.1 .5 \%$ then reject the relay and get a new relay and restart the testing fiom step 6.13

6.1.7. Conned the 5300 relay to the test box as shown in the attached sketch 1 L

Ensure there is no power to the test box when the wires are being connected

6.18. Ensure the sensitivity setting on the 5300 relay is turned fully counter clockyise.

6.1.9. Ensure switch SW 2 is OPEN

6.1.10. Energize the test box and energize the 5300 relay by closing switch SW 1 on the test box. Ensure the Power ON IIght is ON

6.11. Verify the output vollage at terminals 14 and 15 on the 5300 is between 9 and 11.Vdc. Record voltage on data sheet

61. 12 Ensure sWitches SW 3 and SW 4 are OPEN

6.1.13. Place or ensure switches SW 5 and $S W 6$ are in the A $A$ positions

6.11.1. Verify the relay OFP' light is ON

6.1.15. Verify the relay ON Hght IS OFF

6.1 16 Place or ensure switches SW-5 and SW-6 are in the B positions

6.1.17. Verify he "relay OF" 1 ight is ON

6.1.18. Verify the relay ON light is OFF

6.11. 19. Cose switch $\mathrm{SW} 2$

6.1.20. Verify the voltage between terminals 14 and 15 on the 5300 relay is less than Wdo Record on data sheet 
HNF-4275

\section{REVISION 3}

61.21. Ensure switch SW 2 is closed and switches SW 5 and SW 6 are stil in the B position

6.1.22. Verify the "relay OFF" light is OFF

61.23. Verify the "relay ON" light is ON

61.24. Place or ensure switches SW $S$ and SW-6 are in the A positions

6.1.25. Verify the relay OFF" light is OFF

61.26. Venfy the relay ON" Iight is ON

61.27. Open switch $S W-2$ and Push the Reset button

6.128. Ensure switches SW-S and SW 6 in the $A$ positions.

6.1.29. Verify the Telay OFF" light is ON

67.30. Verify the relay $O N$ N light is $O F$

61.31. Place switches SW-5 and SW 6 in the "B" positions

6.1.32. Verify the relay OFF" light is oN

6.133. Verify the relay ON light is OFF

6.1.34. Perform steps 61.21 through 61.33 a total of 10 times. Pause before

performing each switch SW-2 operation Record results on the data sheet

6.135. The 5300 relay passes the bench contact test if the results of all 10 tests are

satisfactory. Any fallure durng any of the 10 tests is considered a failure of the relay

6.136. Open switch SW-1.

61.37. Ensure the "Pover On" Thit is OFF

61.38. Close sWitches SW 3 and SWH

6.139. Close switch SWI1

61.40. Repeat steps 6.1 .13 through 6.135 and record data on data sheets

61. 41 . Open switch SW-1.

6.1.42. Disconnect the 5300 relay from the test box

6.1.43. Quality Assurance Inspector is to sign the data sheet and green tag the 5300 relay as acceptable for installation.

6.1.44. Repeat steps 6.1.3 through 6.1 .43 for each relay. 
HNF-4275

REVISION 3

\subsection{FUNCTIONAL TEST}

6.2.1. Perform the functional test after the leak detector relays (5300-S-V-OC (or 5300-S-F1-OC) and 2313A) are installed and the skid is assembled to the point where $120 \mathrm{vac}$ control power can be applied to the leak detector assembly. Test each of the two leak detector sets separately. Identify relaybeing tested as either SALWLDE-6001 or SAI W-LDE-6002* Record on data sheet

6.2.2. Record the calibration of the digital multimeter on data sheet.

6.2.3. Quality Assurance Inspector to verify part number of MTL relay as "2313A" and record on data table.

6.2.4. Apply $120 \mathrm{vac}$ power to the leak detector assembly either from the skid distribution panel or from a $120 \mathrm{vac}$ power source to the line side of the leak detector fuse block.

6.2.5. Disconnect the wires from terminals 1 and 4 of the MTL 2313A relay.

6.2.6. Apply 3.5 to 4.0 vdc power to the MTL 2313A terminals where positive dc goes to terminal 1 and negative dc goes to terminal 4.

6.2.7. Adjust the MTL 2313A relay to activate (where the red light on the relay is OFF) at 3.5 to 4.0 vdc. Record on the data table.

6.2.8. Disconnect the dc power supply from the MTL 2313A relay.

6.2.9. Reconnect the wires disconnected in step 6.2.5 to the MTL 2313A relay.

6.2.10. Place the selector switch on the front of the panel from the leak detector relays to be tested in the "PROBE TEST" position.

6.2.11. Adjust the 5300 sensitivity (if an adjustable sensitivity relay is used) unit the MTL relay activates (that is the red light OFF). Then add 0.25 to the 5300 sensitivity setting to ensure a margin for activation. Record on data sheet.

6.2.12. Release the selector switch on the front of the panel to return to the OPER A TE" position.

6.2.13. Verify the voltage across terminals 14 and 15 on the 5300 relay and terminals 1 and 4 on the MTL 2313A relay is 9 to $11 \mathrm{vdc}$.

6.2.14. Remove the $120 \mathrm{vac}$ power from the leak detector assembly.

6.2.15. Connect a leak detector probe to the leak detector terminal block as shown in the attached sketch 2 . 
HNF-4275

REVISION 3

6.2.16. Return $120 \mathrm{vac}$ power to the leak detector assembly.

6.2.17. Place the selector switch on the front of the panel to the "OPERATE" position for the leak detector assembly to be tested.

6.2.18. Verify the contacts between terminals 4 and 5 are CLOSED on the 5300 relay.

6.2.19. Verify contacts 3 and 6 are OPEN on the 5300 relay by observing the red light is OFF (nomally located on the front do or of the Instrument Enclosure)

6.2.20. Verify the contacts between terminals 9 and 10 are OPENED, the contacts between terminals 13 and 14 are CLOSED and the red light is ON at the MTL 2313A relay.

6.2.21. Place the selector switch to the "TEST PROBE" position.

6.2.22. Verify the contacts between terminals 4 and 5 are OPENED on the 5300 relay.

6.2.23. Verfy contacts 3 and 6 are $C$ OSED on the 5300 xelay by observing the red Hght IS ON (nomally located on the front door of the Instrument Enclosure)

6.2.24. Verify the contacts between terminals 9 and 10 are CLOSED, the contacts between terminals 13 and 14 are OPENED and the red light is OFF at the MTL 2313A relay.

6.2.25. Return the selector switch to the "OPERATE" position.

6.2.26. Verify the contacts between terminals 4 and 5 are CLOSED on the 5300 relay.

6.2.27. Verify contacts 3 and 6 are OPEN on the 5300 relay by observing the red light IS OFF (normally located on the front door of the Instrument Enclosure)

6.2.28. Verify the contacts between terminals 9 and 10 are OPENED, the contacts between terminals 13 and 14 are CLOSED and the red light is ON at the MTL 2313A relay.

6.2.29. Place the selector switch to the "FAIL" position.

6.2.30. Verify the contacts between terminals 4 and 5 are CLOSED on the 5300 relay.

6.2.31. Verify contacts 3 and 6 are CLOSED on the 5300 relay by observing the red light is oN (normally located on the front door of the lnstrument Enclosure)

6.2.32. Verify the contacts between terminals 9 and 10 are CLOSED, the contacts between terminals 13 and 14 are OPENED and the red light is OFF at the MTL 2313A relay.

6.2.33. Return the selector switch to the "OPERATE" position. 
HNF-4275

REVISION 3

6.2.34. Verify the contacts between terminals 4 and 5 are CLOSED on the 5300 relay.

6.2.35. Nerify contacts 3 and 6 are OPEN on the 5300 relay by observing the red light IS OPF (nomnally 10 ated on the front door of the Instrument Enclosure)

6.2.36. Verify the contacts between terminals 9 and 10 are OPENED, the contacts between terminals 13 and 14 are CLOSED and the red light is ON at the MTL 2313 A relay.

6.2.37. Place the leak detector probe into a bucket of water.

6.2.38. Verify the contacts between terminals 4 and 5 are OPENED on the 5300 relay.

6.2.39. Venfy contacts 3 and 6 are CLOSED on the 5300 relay by observing the red Thit is ON (nomaly located on the front door of the Instrument Enclosure)

6.2.40. Verify the contacts between terminals 9 and 10 are CLOSED, the contacts between terminals 13 and 14 are OPENED and the red light is OFF at the MTL 2313 A relay.

6.2.41. Remove the leak detector from the bucket of water.

6.2.42. Verify the contacts between terminals 4 and 5 are CLOSED on the 5300 relay.

6.2.43. Nerify contacts 3 and 6 are OPEN on the 5300 relay by observing the red light IS OFF (nomally tocated on the front door of the Instrument Enclosure)

6.2.44. Verify the contacts between terminals 9 and 10 are OPENED, the contacts between terminals 13 and 14 are CLOSED and the red light is ON at the MTL 2313 A relay.

6.2.45. Remove the power from the leak detector assembly being tested.

6.2.46. Disconnect the leak detector probe from the relay set being tested.

6.2.47. Quality Assurance Inspector to sign the data table upon successful completion of the functional tests.

6.2.48. Repeat steps 6.2 .1 through 6.2 .47 for the other leak detector relay set. 
HNF-4275

REVISION 3

\section{SAFETY}

This test procedure creates no unique safety hazard. Standard electrical practices are to be used for performing voltage checks on low voltage equipment. Voltages encountered in this test are 5 volts dc and 120 volts ac.

\section{QUALITY ASSURANCE}

Quality Assurance Inspector shall witness the performance of this test procedure. Quality Assurance Inspector shall be responsible to sign the completed data sheets along with engineering and green tag those relays that successfully complete the testing.

\section{ORGANIZATION AND FUNCTION RESPONSIBILITIES}

Lockheed Martin Hanford Corporation shall provide the engineering support to ensure the proper test procedure is prepared and the Commercial Grade Item (CGI) dedication forms are completed prior to use of the leak detection relays.

Site Fabrication Services shall perform this test procedure for leak detection relays used in the fabrication of new PIC skids.

\section{SCHEDULE}

The bench test shall be performed prior to the relays being installed in the PIC skids. The functional test shall be performed during the ATP of the PIC skids that are fabricated.

\section{REPORTS}

The CGI forms and attached data sheets shall be the official test record. A formal test report will not be issued.

\section{REFERENCES}

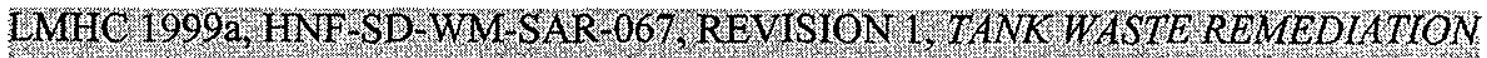
SISTEM FINAT SAFETY INAL YSTSREPORT October 1999.

LMITO 1999b, HNF-IP-0842, VOLUME IV, SECTION 3.11, REVISION 3b, COMMERCIAL GRADE ITEM UPGRADE, Oetober 1999.

\section{DATA SHEETS}

Typical data sheets are in the appendix. A completed copy of each data sheet shall be part of the completed CGI form. 
HNF-4275

REVISION 3

\section{APPENDIX}

TEST DATA SHEETS

1. BENCH TEST DATA SHEET

2. FUNCTIONAL TEST DATA SHEET 

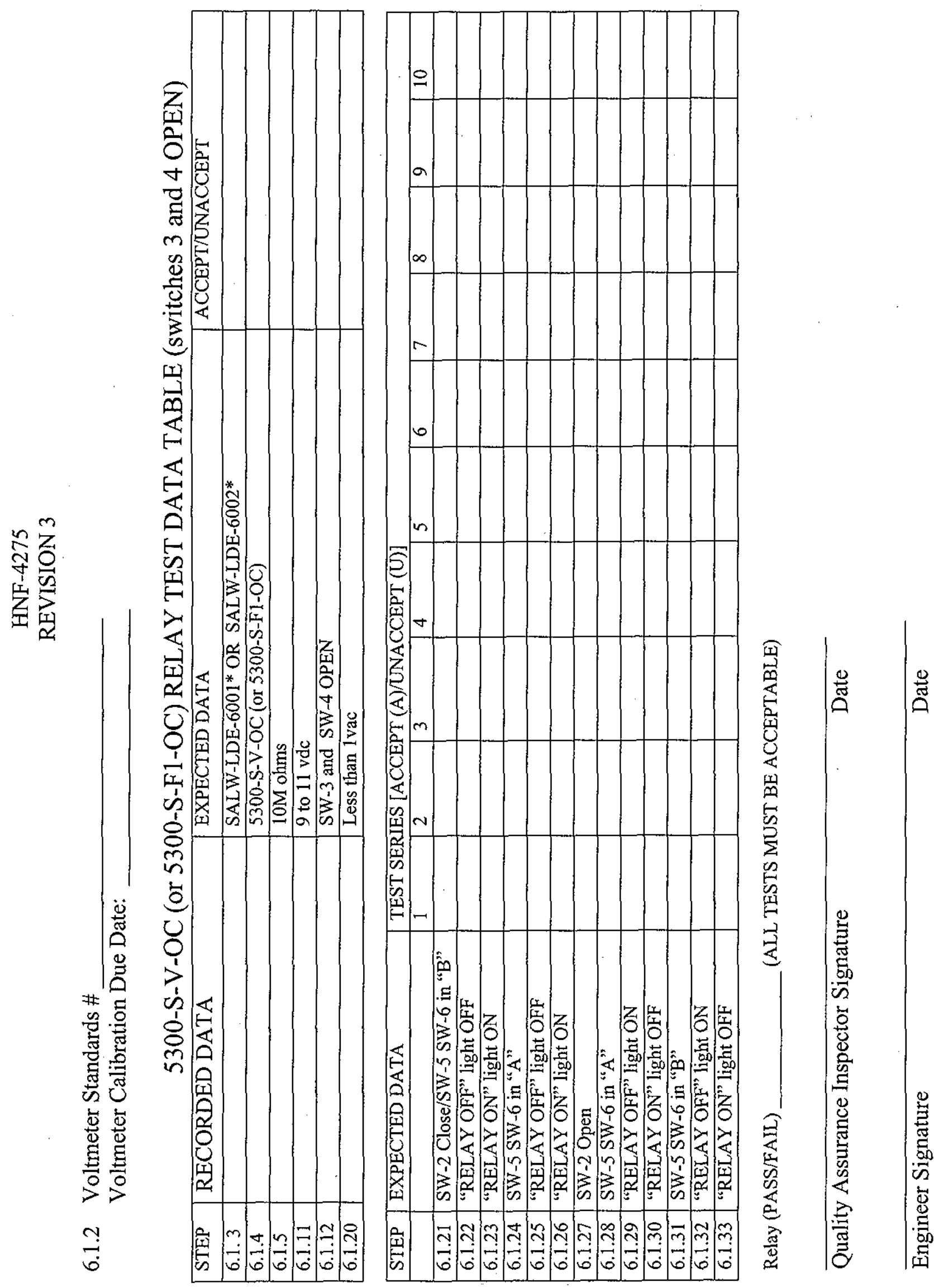

$n$
5
0
$=$ 


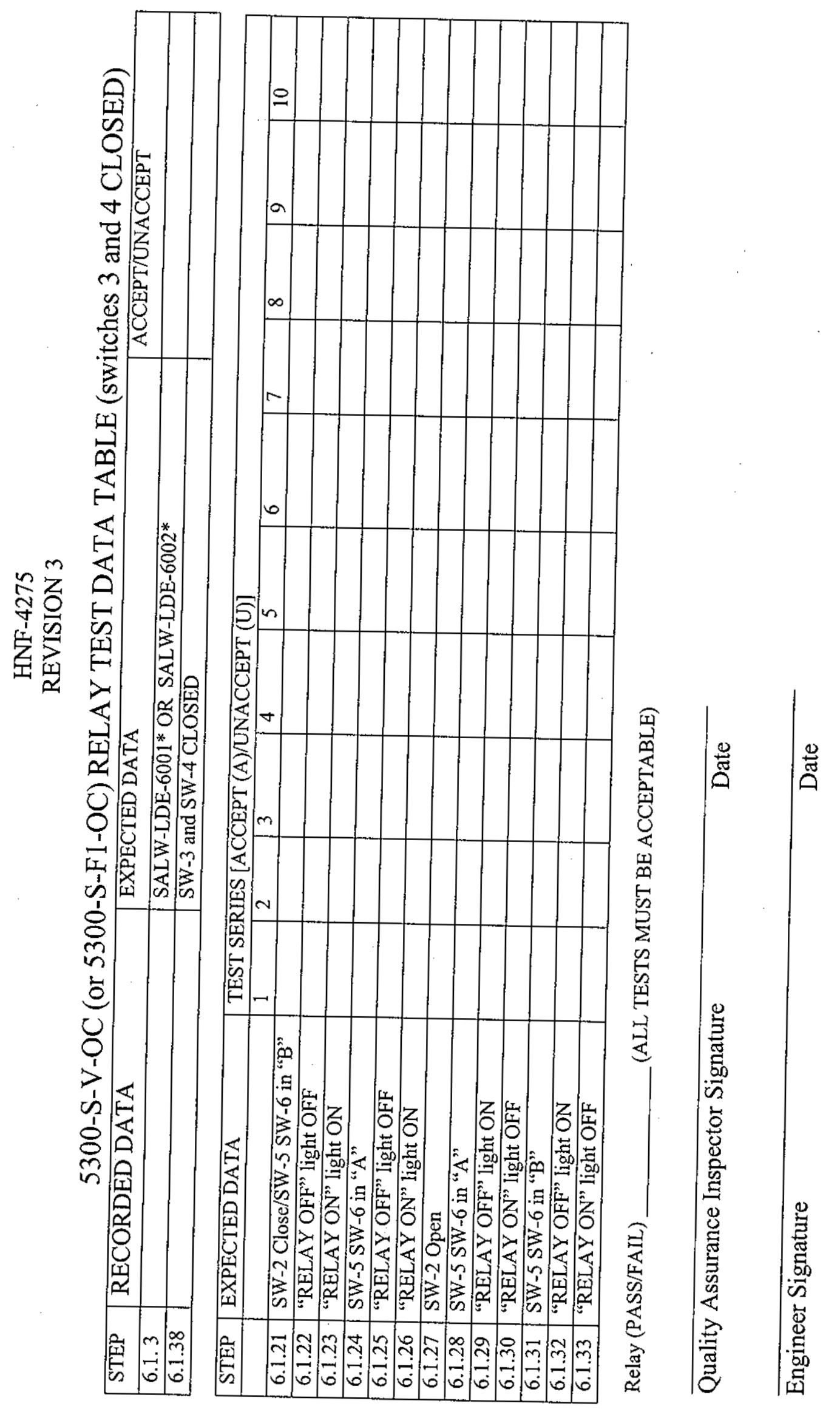

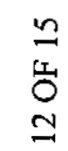




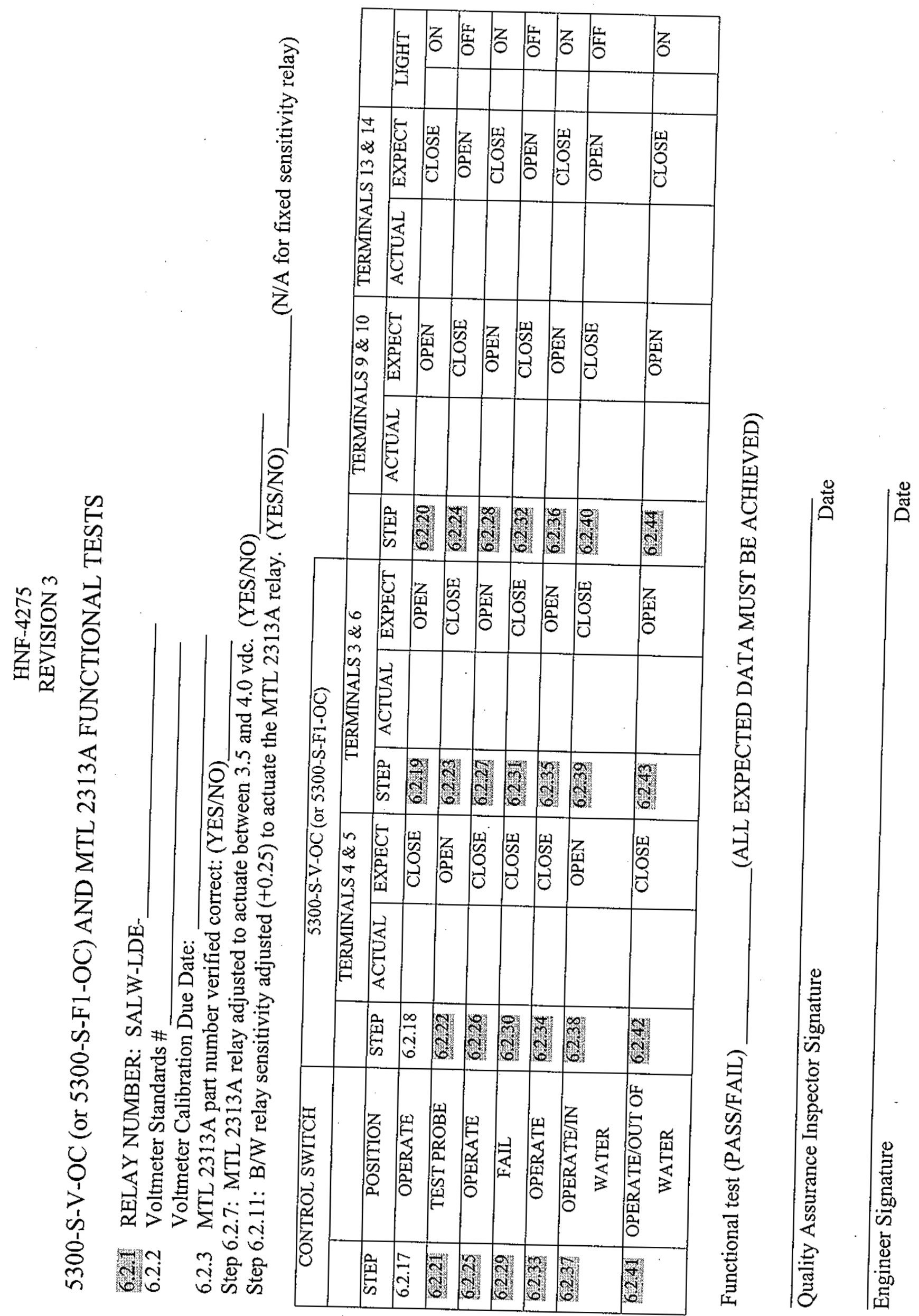

$n$
2
0
0
$m$ 
HNF-4275

REVISIDN 3

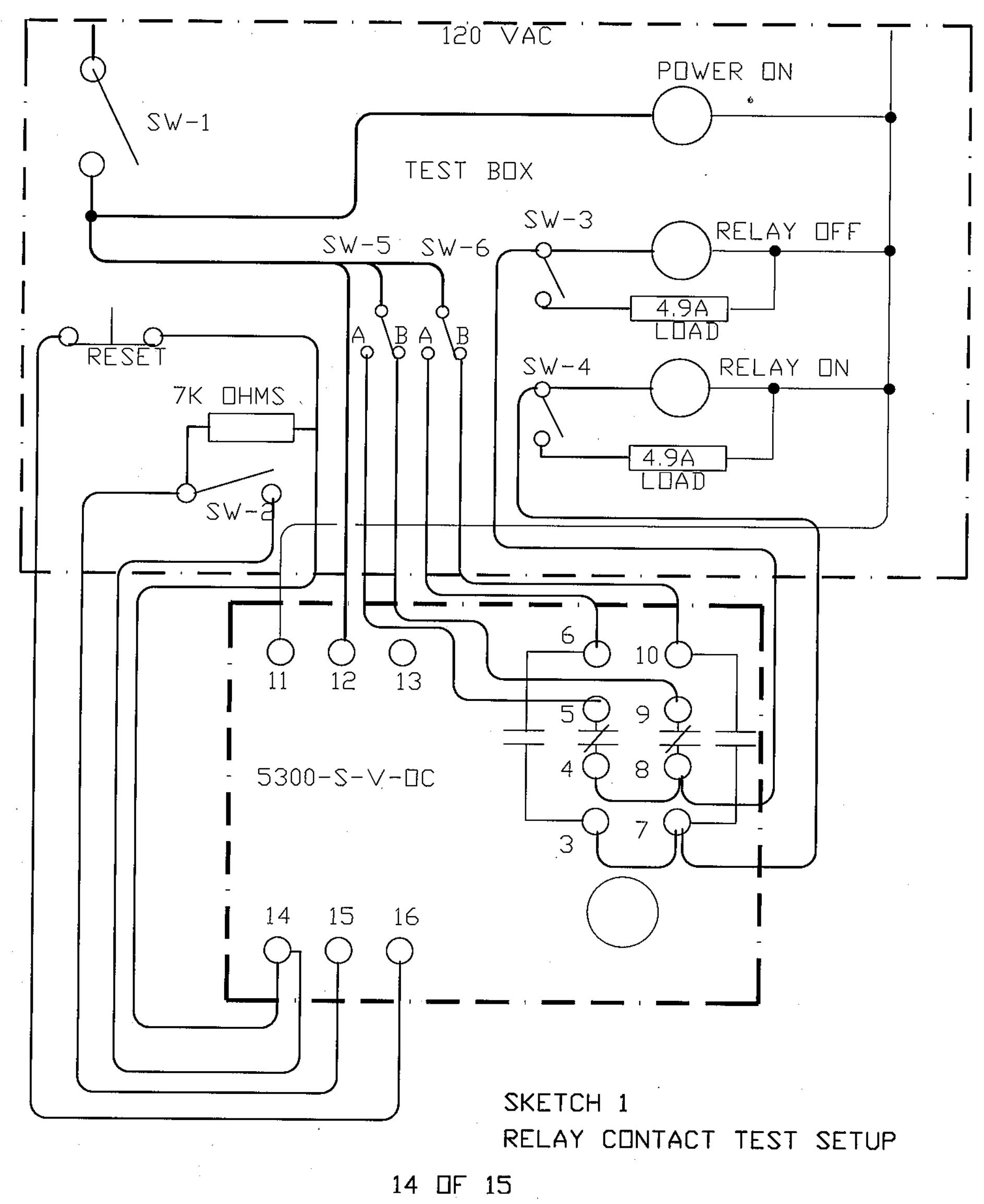




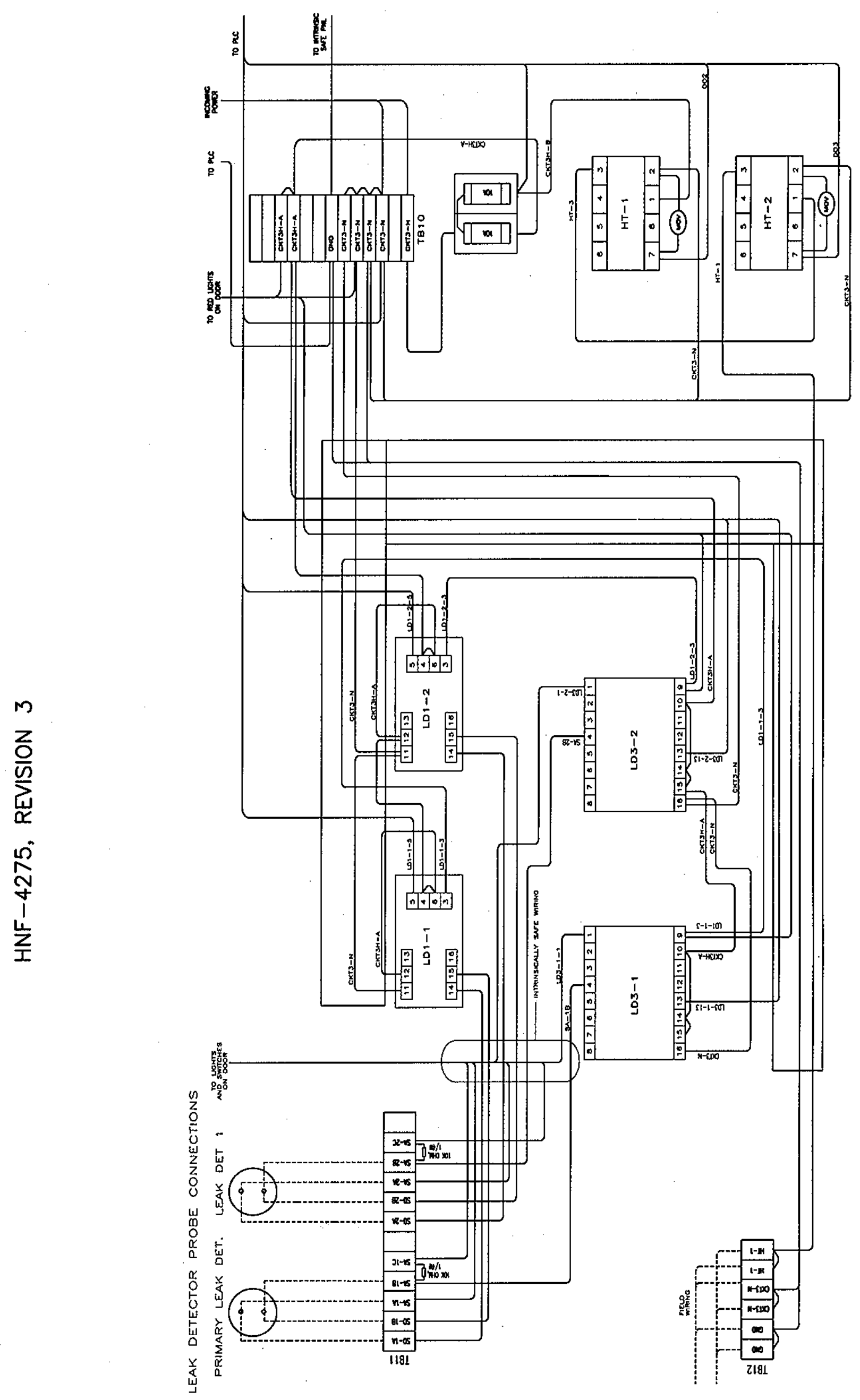

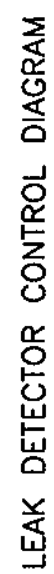

